\title{
Changes of Endothelin-1 Receptors Activity in Induced-Hyperthyroid Isolated Rat Aorta
}

\begin{tabular}{|c|c|}
\hline & Isma \\
\hline \multicolumn{2}{|c|}{ Abstract } \\
\hline \multicolumn{2}{|c|}{$\begin{array}{l}\text { Background and objective: Endothelin has an excessive diverse set of actions that affect } \\
\text { homeostatic mechanisms throughout the body. The current study was designed to show } \\
\text { the effects of induced-hyperthyroid on the ET-1 receptor and their antagonists were } \\
\text { investigated. } \\
\text { Methods: The study was carried out with two group of female rats: control and } \\
\text { induced-hyperthyroidism. Induced-hyperthyroidism in rats occurred by administration of } \\
\text { L-thyroxin for four weeks. The results confirmed the induction of hyperthyroidism because } \\
\text { L-thyroxine-treated rats associated with increased serum levels T3 and T4. } \\
\text { Results: In an in vitro study, the dose-response curve (DRC) of ET-1 were found in } \\
\text { isolated intact and denuded aortic rings of both control and induced-hyperthyroid groups. } \\
\text { On the other hand, denudation of aortic rings shifted the DRC of ET-1 to the left and the } \\
\text { pD2 increased non-significantly in control group. The pD2 significantly increased in } \\
\text { induced-hyperthyroid aortic rings and shifted the DRC of ET-1 to the left. Furthermore, pre } \\
\text {-incubation with selective endothelin-A (ETA) receptor antagonist (BQ-123) shifted the } \\
\text { DRC of ET-1 to the right in both groups and significantly reduced pD2 in control aortic } \\
\text { rings. Selective endothelin B (ETB) receptor antagonist (BQ-788) pre-incubation } \\
\text { significantly raised the pD2 value in both groups and shifted the DRC to the left in } \\
\text { induced-hyperthyroid aortic rings, while it decreased Emax in control and increased in } \\
\text { induced-hyperthyroid aortic rings. } \\
\text { Conclusion: In induced-hyperthyroid rats BQ-788, but not BQ-123 enhanced contractile } \\
\text { response to ET-1 Pre-incubation of BQ-123 did not lead to change the contractile } \\
\text { response of denuded rings in control rats, but pre-incubation of this antagonist in } \\
\text { hyperthyroid denuded aortic rings led to inhibition of contractile response to ET-1. } \\
\text { Keywords: Endothelin-1; ET A and ETB receptors; Hyperthyroidism; Isolated Rat Aorta. }\end{array}$} \\
\hline troduction & \\
\hline $\begin{array}{l}\text { Endothelin-1, a } 21 \text {-amino-acid long peptide } \\
\text { isolated from the cultured endothelial cells, } \\
\text { it has long-lasting vasoconstriction activity } \\
\text { in most vascular smooth muscle cells } \\
\text { (VSMCs). }{ }^{1} \text { ET-1 has two main receptors, } \\
\text { ETA and ETB; ETA receptors are } \\
\text { expressed on VSMCs and ETB receptors } \\
\text { on both endothelial and. }{ }^{2} \text { The ETA } \\
\text { antagonist BQ-123 also improved the } \\
\text { impairment of vasodilation in hypertensive } \\
\text { patients, whereas BQ- } 788 \text {, the ETB } \\
\text { antagonist, exerted a vasoconstrictor effect } \\
\text { on forearm resistance arteries in }\end{array}$ & $\begin{array}{l}\text { express both ETA and ETB receptors. }{ }^{4} \\
\text { Endothelin A receptors are expressed } \\
\text { on SMCs that contract on activation. In } \\
\text { contrast, ETB receptors are expressed } \\
\text { both on smooth muscle cells to evoke } \\
\text { contractions and endothelial cells to induce } \\
\text { NO and EDHF-dependent relaxation. }{ }^{5} \\
\text { Depending on a type of cell, type of tissue } \\
\text { or physiological situations, ETA and } \\
\text { ETB receptors can possess synergetic or } \\
\text { opposing effects. }{ }^{6} \text { Vascular endothelial } \\
\text { cells appear to express ETB receptors } \\
\text { primarily, and the activation of these ETB }\end{array}$ \\
\hline
\end{tabular}


receptors increases intercellular [Ca+2], resulting in increased $\mathrm{NO}$ production and vasodilation. ${ }^{7}$ Endothelin has an excessive diverse set of actions that affect homeostatic mechanisms throughout the body. ET-1 is a potent and long-lasting vasoconstrictor both in vivo and in-vitro. ${ }^{8}$ It has a greater role in the maintenance of vascular tone and modulation. ${ }^{9}$ Endothelins also promote growth and proliferation of VSMCs, an effect that appears to be ETA receptor-mediated and involves activation of mitogen-activated protein (MAPK)s and perhaps the transactivation of epidermal growth factor receptor. ${ }^{10}$ Endothelial dysfunction is a result of an imbalance between vasoconstriction and relaxing factors, procoagulant and anticoagulant substances, as well as among proinflammatory mediators. Detection of ED based on the assessment of circulating markers of endothelial function; ET-1..11,12 In thyroid carcinoma, the overexpression of ET-1 and ETA receptor observed these suggest a mitogenic role of ET-1 that could be countered theoretically via ETA receptor antagonists. Also, in thyroiditis overexpression of ET-1 and ETA receptor supports the ET-1 role in the inflammatory process. ${ }^{13}$ However, in hyperthyroidism, vascular tones will change, but according to our knowledge, the exact mechanism for such changes is not fully understood. Therefore, the present study aimed to investigate the role of ET-1 receptors in induced-hyperthyroid rat aortic constriction -induced by ET-1.

\section{Methods}

\section{Animals and housing}

Female albino rats of about weighting 200-300gm used in the present study. Animals were housed and bred in the animal house belong to Biology Department, College of Science; Salahaddin University Erbil. The animals kept in plastic cages (4-5 rats/cage) bedded with wood chips and given a standard rat diet and tap water ad libitum. The animals housed in standard laboratory conditions of light and temperature (12 hrs. light: $12 \mathrm{hrs}$. dark photoperiod and $22 \pm 4 \mathrm{oC}$ ).

\section{Induction of hyperthyroidism}

Animals were induced thyrotoxicosis by administration of L-thyroxin $(0.4 \mathrm{mg} / 100 \mathrm{~g}$ food) (BERLIN-CHEMIE AG -Berlin, Germany) for four weeks. Hyperthyroidism confirmed by determination of serum T3 and T4. Both hormones significantly elevated as compared to the control rats.

\section{Animal ethics}

The care of animals has been approved by the animal research committee in Salahaddin University-Erbil. The study protocol has been endorsed by the ethics committee of our department.

\section{Estimation of serum T3 and T4}

Triiodothyronine, thyroxine were determined by a fully automated immune analyzer (Cobas e 411 Roche Diagnostics, HITACHI, Japan) based on the ECL technology.

\section{Preparation of aortic rings}

Female albino rats were injected with heparin (1500units $/ \mathrm{kg}$ body weight) to avoid blood clotting and possible damage of aortic endothelium and anesthetized with the injection of ketamine $(40 \mathrm{mg} / \mathrm{kg})$ and xylazine $(10 \mathrm{mg} / \mathrm{kg})$ intraperitoneal (Struck et al., 2011). The animal abdomen wall opened until chest cavity, after that excess fat tissues removed to obtain the appropriate length of rings and isolate it smoothly without being stretching and any mechanical force to get intact aorta. In experiments on denuded endothelial cells, the isolated aorta gently rubbed by cotton many times to get denuded aorta. The aorta transferred to a petri-dish filled with cold Krebs-Henseleit solution aerated with about $95 \%$ oxygen in 37 Co. Krebs solution is a physiological buffered solution that contains $(\mathrm{NaCl}$ 0.118, NaHCO3 0.025 , MgSO $4 \quad 0.0012, \quad \mathrm{KCl} 0.0047, \mathrm{KH} 2 \mathrm{PO} 4$ $0.0012, \quad \mathrm{CaCl} 20.0025, \mathrm{C} 6 \mathrm{H} 12 \mathrm{O} \quad 0.011$ and EDTA 0.001) in mole/L with $\mathrm{pH} 7.4$. These solution maintains the viability of the cell, provide the suitable conditioner medium for it and has a sensitive $\mathrm{pH}$ for that reason should be used freshly. 
The aortic rings then cut into 4-segments each with $2-2.5 \mathrm{~mm}$ length approximately. The confirmation to ensure the denudation, the aortic rings was contracted by $(\mathrm{KCl}$ $60 \mathrm{mM}$ ) then relaxed by $\mathrm{ACh}$, if the muscle not relaxed, then the aorta denuded.

Isometric tension recording in isolated vessel

The aortic rings held up by two stainless steel clamps (Tissue clamp, Model Le 0140, Panlab Harvard Apparatus, USA). One of the clamps connect to a hook at the bottom of the organ bath jacket, and the other was connected to the force transducer through a thread to record vibrations from the rings to transduce it by the amplifier (Quad bridge amplifier Powerlab 8/35) (Fig 3.4). Isometric tension detected by the transducer which is connected to the amplifier when the muscle of the ring contracts or relax, and the data recorded by data acquisition software (LabChart 7.1). Then the aortic rings immersed in Krebs solution contained in a $10 \mathrm{ml}$ organ chamber. Krebs solution was maintained at $\mathrm{pH} 7.4$ and continuously aerated with carbogen in about 95\% oxygen $5 \%$ carbon dioxide at $370 \mathrm{C}$ (LE 13206 Thermostat, Panlab Harvard Apparatus, USA). The aortic rings were tensed to a stable basal strain of $2 \mathrm{gm}$ before left to equilibrate for an $\mathrm{hr}$. To remove any cellular metabolites, Krebs solution was replaced every 15-20 minutes intervals in the bath chamber. After stabilization, the viability test was performed to know whether the aorta is still alive or not by pre-contraction with $\mathrm{KCl}$ $60 \mathrm{mM}$ (EC50, Dose response curve previously obtained in the laboratory). In order to reach stability of the aorta, it washed many times and the experimental substances introduced into bath chambers according to the protocols. The DRC for ET -1 (10-10 - 10-7M) obtained in the absence of incubation also, the aorta incubated with chemicals for 20 minutes then ET -1 (10-10 - 10-7M) DRC received in time interval of 8 minutes.

\section{Experimental design}

The in vitro experiment was done using isolated thoracic aorta pre-incubated with ET-1 receptor antagonists. DRC was found for ET-1 (Bachem AG Company, Germany) in intact and denuded aortic rings of both control and Induced-hyperthyroid rats. Also, the experiment carried out to investigate the roles of ETA and ETB receptors in aortic smooth muscle tone in both control and induced hyperthyroid rats. Here EC50 was calculated for ET-1 dose response curve in the absence and presence of selective ETA (BQ-123) (Bachem AG Company, Germany) and selective ETB receptor antagonists (BQ788) (BachemAGCompany, Germany). Furthermore, these ET-1 receptor antagonists also applied to denuded aortic smooth muscle tissues.

The following groups included:

\section{Group 1: Dose - response curve of ET-1} (Control)

Aortic rings of control and induced hyperthyroid rats were allowed to equilibrate for $60-90 \mathrm{~min}$ at $2 \mathrm{~g}$ tension. The dose-response curve and the EC50 obtained for ET $-1(10-10-10-7 \mathrm{M})$ by its cumulative addition with time interval 8 minutes to organ bath in both intact $(n=5$ control, $n=8$ TIH) and denuded aortic rings ( $n=8$ control, $n=7 \mathrm{TIH}$ ).

\section{Group 2: BQ-123 (ETA Receptor antagonist)}

The aortic rings of control and induced hyperthyroidism pre-incubated with selective ETA Receptor antagonist (BQ$123,0.3 \mu \mathrm{M})$ for 20 minutes. DRC and EC50 obtained for ET-1 (10-10 - 10-7M) by its cumulative addition with time interval 8 minutes to organ bath in both intact $(n=6$ control, $n=8 \mathrm{TIH})$ and denuded aortic rings $(n=8$ control, $n=8 \mathrm{TIH})$.

\section{Group 3: BQ-788 (ETB Receptor antagonist)}

The aortic rings of control $(n=8)$ and induced hyperthyroidism $(n=5)$ preincubated with selective ETB Receptor antagonist (BQ-788, $1 \mu \mathrm{M})$ for 20 minutes then DRC and EC50 obtained for ET-1 
(10-10 - 10-7M) by its cumulative addition with time interval 8 minutes to organ bath in intact aortic rings.

\section{Data analysis}

ET-1 induced contractions expressed as a percentage, and for each dose-response curve the maximum effect (Emax) and the concentration of ET-1 which produced half of Emax (EC50) were calculated. Maximum effects expressed as mean \pm S.E.M. and EC50 as the geometric mean with its confidence limits (95\%) for repeated experiments. Statistical comparisons of Emax and -log EC50 (pD2) values of the dose-response curves for ET-1 obtained with the different treatments in the arteries achieved by a post hoc Bonferroni's multiple-comparison test. The data considered to be significantly different when $P<0.05$.

\section{Results}

The present results show that ET-1 induced- aortic ring contraction (ET-1, 10-10-10-7 M) for each control and induced-hyperthyroid rats are shown in the Table 1, Figure 1. The pD2 value of concentration-response curve for ET-1 was non-significantly lower in aortic rings in induced-hyperthyroid rats than in aortic rings of control rats.

Table 1: Maximum efficacy (Emax) and $\mathrm{pD}_{2}$ values of dose-response curves for the effects of ET-1 receptor antagonists on response to ET-1 in control and induced-hyperthyroidism in rats isolated intact and denuded aortic rings.

\begin{tabular}{lcccc}
\hline & \multicolumn{2}{c}{ Control } & \multicolumn{2}{c}{ Induced-Hyperthyroidism } \\
& $E_{\max }$ & $\mathrm{pD}_{2}$ & $\boldsymbol{E}_{\max }$ & $\mathrm{pD}_{2}$ \\
\hline Control Intact & $115.1 \pm 12.65$ & $7.499 \pm 0.208$ & $100.0 \pm 21.51$ & $7.007 \pm 0.500$ \\
BQ-123 Intact & $103.1 \pm 4.526$ & $6.125 \pm 0.436$ & $100.0 \pm 20.84$ & $6.639 \pm 0.763$ \\
BQ-788 Intact & $88.94 \pm 10.96$ & $7.517 \pm 0.190$ & $143.7 \pm 24.68$ & $7.669 \pm 0.264$ \\
Control denuded & $100.0 \pm 20.92$ & $8.220 \pm 0.276$ & $100.0 \pm 14.02$ & $8.260 \pm 0.187$ \\
BQ-123 denuded & $100.0 \pm 11.49$ & $7.868 \pm 0.217$ & $100.0 \pm 2.544$ & $7.544 \pm 0.082$ \\
\hline
\end{tabular}

Values are means \pm S.E. Emax $=$ maximum efficacy, $\mathrm{pD}_{2}=-\log \mathrm{EC}_{50}$.

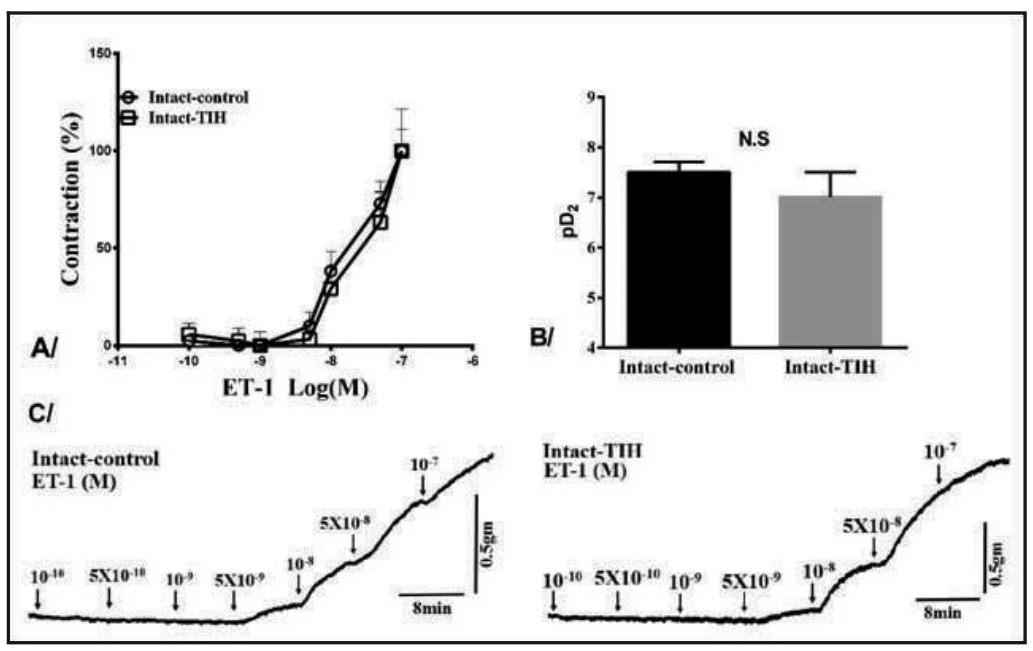

Figure 1: Dose -response contractile curve for ET-1 in intact aortic rings of control and thyroxine-induced hyperthyroidism (TIH) (A). $\mathrm{pD}_{2}$ value for ET-1 in both groups (B), A Typical chart view traces $(C)$. Values represented as mean \pm S.E. 
The contractile potency of ET-1 and their DRC, did not change in endotheliumdenuded aortic rings of thyroxine-induced hyperthyroidism comparing to control rats as shown in the Table 1 and Figure 2. Furthermore, as seen in the Table 1, Figure 3 and 4 mechanical removal of endothelial cells in both groups, nonsignificantly increased the pD2 value of ET-1 in control aortic rings. While, significantly $(P<0.001)$ increased pD2 values of the concentration-response curves for ET-1 from (7.007 \pm 0.500 to $8.260 \pm 0.187)$. It means that the contractile potency of ET-1 increased significantly. Endothelial denudation shifted the DRC of ET-1 to the left versus intact endothelium, and it has a significant difference with endothelium-intact DRC of $\mathrm{ET}-1$ at the dose $\left(10^{-8} \mathrm{M}\right)$.

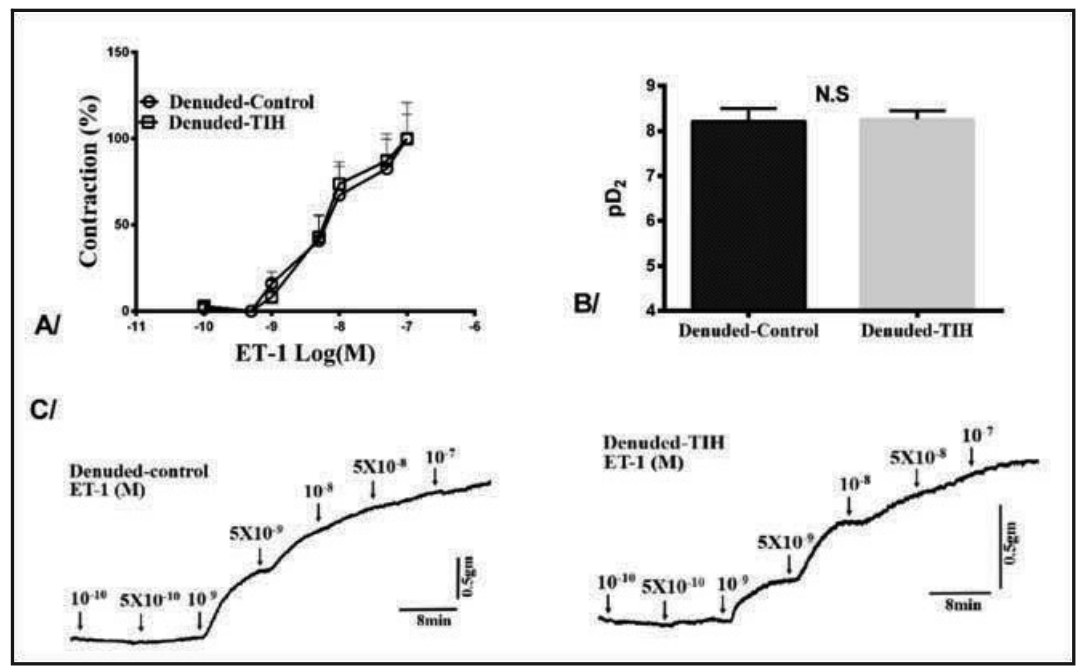

Figure 2: Dose -response contractile curve for ET-1 in denuded aortic rings of control and thyroxine-induced hyperthyroid rats $(\mathrm{TIH})(\mathrm{A})$. $\mathrm{pD}_{2}$ value for $\mathrm{ET}-1$ in both groups $(\mathrm{B})$, A Typical chart view traces (C). Values represented as mean \pm S.E.

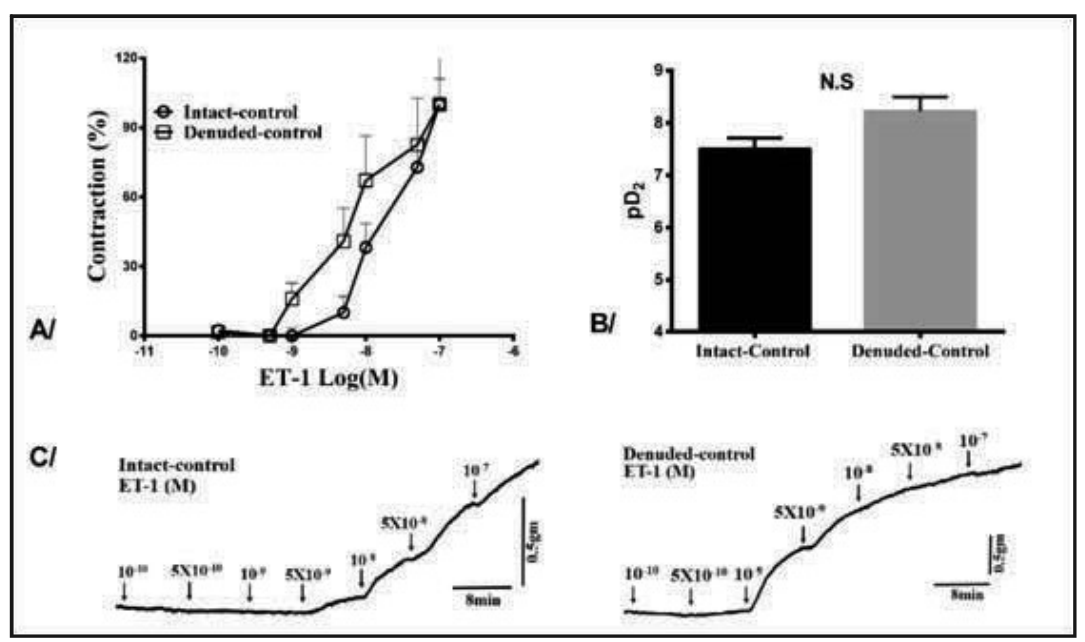

Figure 3: Dose -response contractile curve for ET-1 in intact and denuded aortic rings of control rats (A). $\mathrm{pD}_{2}$ value for ET-1 in intact and denuded aortic rings (B), A Typical chart view traces $(C)$ Values represented as mean \pm S.E. 
Our data presented that incubation of control intact aortic rings with ETA receptor antagonist (BQ-123, $0.3 \mu \mathrm{M})$ for 20 min decreased the contractility of ET-1 produced vasoconstriction with rightward displacements of the ET-1 DRC and caused a significant reduction of the $\mathrm{pD} 2$ value $(7.499 \pm 0.208$ control versus $B Q$ $1236.125 \pm 0.436$ ). Also, it is significantly different at doses $\left(10-8 \mathrm{M}\right.$ and $5 \times 10^{-8} \mathrm{M}$ versus control). While, pre-treatment of control intact aortic rings with the ETB receptor antagonist $(\mathrm{BQ}-788,1 \mu \mathrm{M})$ for 20 minutes significantly increased the pD2 value in comparison with DRC for an ET-1in absence of antagonists of control rings $(7.499 \pm 0.208$ control versus BQ-788 $7.517 \pm 0.190)$. It also decreased Emax significantly from $115.1 \pm 12.65$ of control to $88.94 \pm 10.96$ of $\mathrm{BQ}-788$. Moreover, there is a significance $P<0.05$ difference of $\mathrm{pD} 2$ value between the DRC of ET-1 pre -incubated with BQ-123 and DRC of ET-1 pre-incubated with $\mathrm{BQ}-788$, Table 1 and Figure 5.

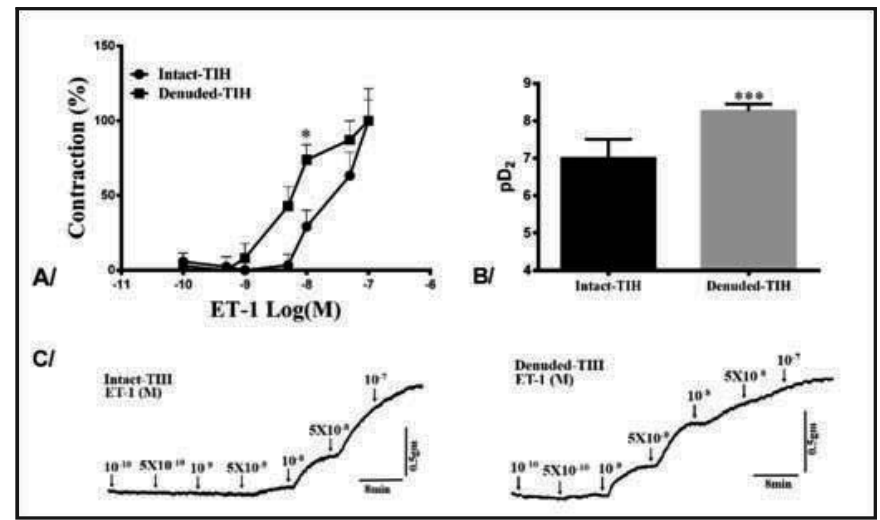

Figure 4: Dose -response contractile curve for ET-1 in intact and denuded aortic rings of thyroxine-induced hyperthyroid rats $(\mathrm{TIH})(\mathrm{A})$. The $\mathrm{pD}_{2}$ value for $\mathrm{ET}-1$ (B). A Typical chart view traces $(C)$. The star sign shows the comparison with Intact- $\mathrm{TIH},{ }^{*} P<0.05$, ${ }^{* * *} P<0.001$. Values represented as mean $\pm \mathrm{S}$.E.

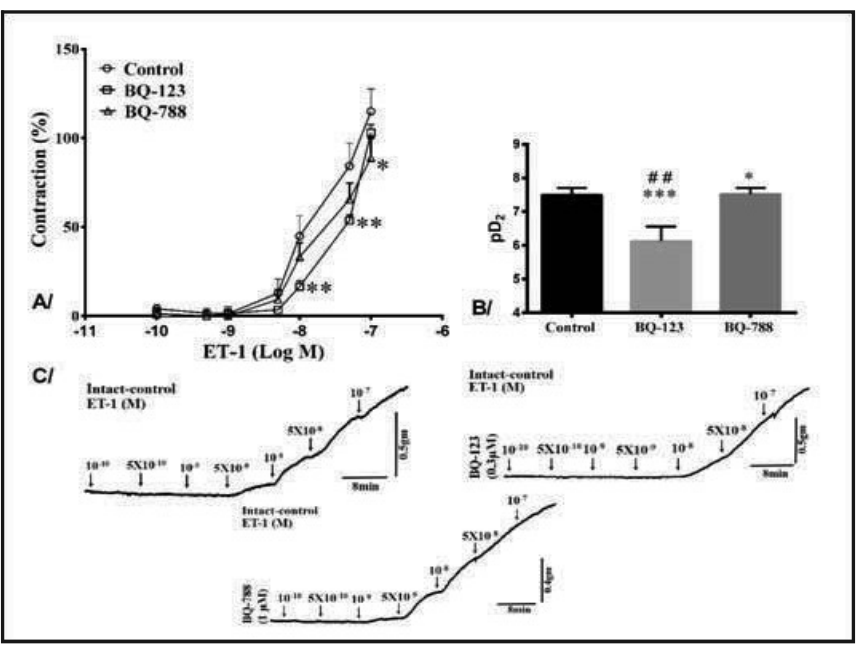

Figure 5: Dose -response contractile curve for ET-1 in intact aortic rings with absence (Control) and presence of $\mathrm{ET}_{\mathrm{A}}$ receptor antagonist (BQ 123, $\left.0.3 \mu \mathrm{M}\right)$ and $\left.\mathrm{BQ}-788,1 \mu \mathrm{M}\right)$ in rats with control (A). The $\mathrm{pD}_{2}$ value for $\mathrm{ET}-1$ (B). A Typical chart view traces (C). The star sign show the comparison with control: ${ }^{*} P<0.05,{ }^{* *} P<0.01,{ }^{* * *} P<0.001$ while hash sign show comparison with BQ-788, \# \#P<0.01.Values represented as mean \pm S.E. 
Pre-incubation of induced-hyperthyroid intact aortic rings with ETA receptor antagonist (BQ-123, $0.3 \mu \mathrm{M})$ for 20 min non -significantly affected the ET-1 induced contraction in a concentration-dependent manner decreased pD2 and without the change in Emax. In contrast, pre-treatment of intact aortic rings in inducedhyperthyroid rats with the ETB receptor antagonist (BQ-788, 1 $\mu \mathrm{M})$ for 20 minutes led to a significant change in the ET-1 induced contraction. It also shifted the curve to the left and increased $\mathrm{pD} 2$ value $\mathrm{p}<0.001$ from $7.007 \pm 0.500$ of $\mathrm{TIH}$ to 7.669 \pm 0.264 of $\mathrm{TIH}-\mathrm{BQ}-788$. As well as Emax from $100.0 \pm 21.51$ of $\mathrm{TIH}$ to $143.7 \pm 24.68$ of $\mathrm{TIH}-\mathrm{BQ}-788$. Also, it is significantly different with DRC for ET-1in intact aortic rings of $\mathrm{TIH}$ at doses $\left(5 \times 10-8 \mathrm{M}\right.$ and $10^{-7}$ $M)$. Despite these, there is a significant difference observed between intact aortic rings pre-incubated with $\mathrm{BQ}-123(0.3 \mu \mathrm{M})$ and intact aortic rings pre-incubated with $\mathrm{BQ}-788(1 \mu \mathrm{M})$ of $\mathrm{pD} 2$ value from $6.639 \pm$ 0.763 of $\mathrm{TIH}-\mathrm{BQ}-123$ to $7.669 \pm 0.264 \mathrm{TIH}-$ $B Q-788$. The Emax significantly increased from $100.0 \pm 20.84$ of $\mathrm{TIH}-\mathrm{BQ}-123$ to 143.7 \pm 24.68 of $\mathrm{TIH}-\mathrm{BQ}-123$. Besides, the DRC of ET-1 pre-incubated with $B Q-123$ $(0.3 \mu \mathrm{M})$ significantly different at doses (10$8 \mathrm{M}, 5 \times 10^{-8} \mathrm{M}$, and $\left.10-7 \mathrm{M}\right)$ in comparison with $\mathrm{TIH}-\mathrm{BQ}-788$ as shown in the Table 1 and Figure 6.

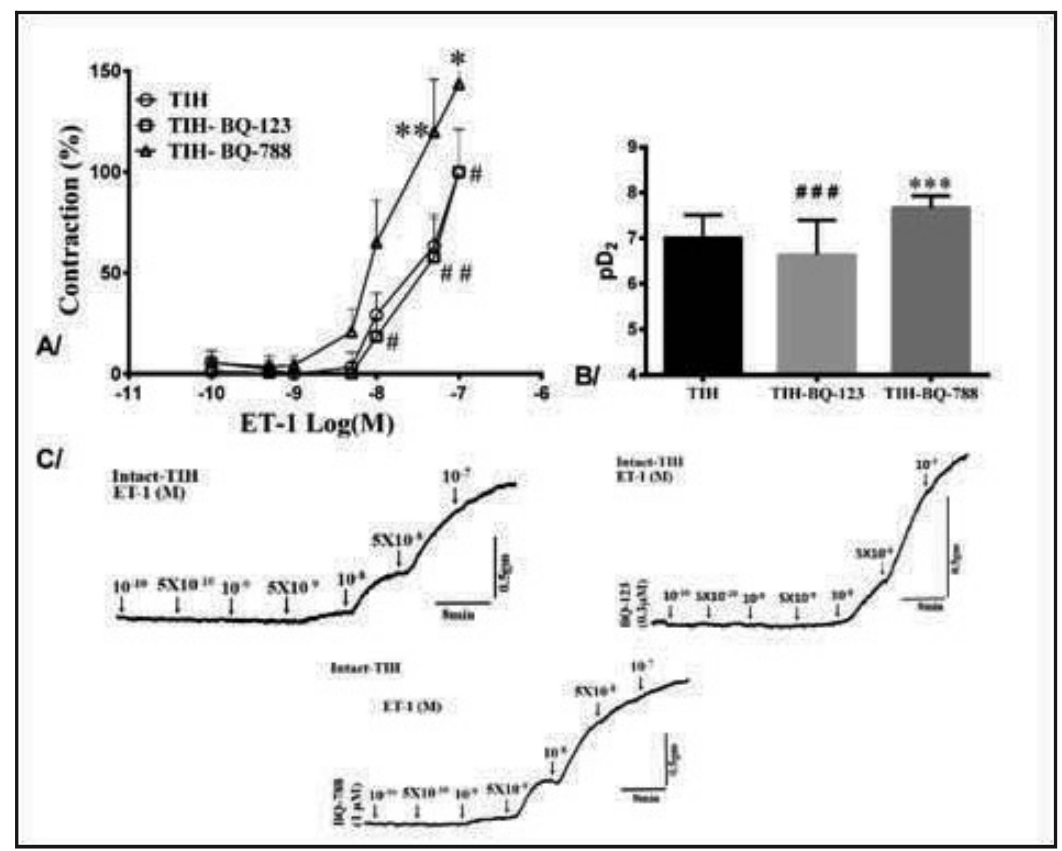

Figure 6): Dose -response contractile curve for ET-1 in intact aortic rings with absence (Control) and presence of $\mathrm{ET}_{\mathrm{A}}$ receptor antagonist (BQ 123, $\left.0.3 \mu \mathrm{M}\right)$ and $\left.\mathrm{BQ}-788,1 \mu \mathrm{M}\right)$ in thyroxine-induced hyperthyroidV $(\mathrm{TIH})$ rats $(\mathrm{A})$. The $\mathrm{pD}_{2}$ value for $\mathrm{ET}-1$ (B). A Typical chart view traces $(\mathrm{C})$. The star sign show the comparison with $\mathrm{TIH},{ }^{*} P<0.05,{ }^{* *} P<0.01$, ${ }^{* * *} P<0.00$ while hash sign show comparison with TIH-BQ-788, \# $P<0.05$, \# \#P<0.01, \# \# $\# P<0.001$. Values represented as mean $\pm \mathrm{S}$.E. 
Pre-incubation of denuded aortic rings with ETA receptor antagonist (BQ-123, $0.3 \mu \mathrm{M}$ ) for 20 minutes in control slightly shifted the DRC for ET-1 to the right and nonsignificantly slightly reduced pD2 value as seen in the Table 1 and Figure 7. Contrary, BQ-123 pre-incubated in denuded aortic rings of induced-hyperthyroid group augmented the contractile potency of ET-1, significantly decreases ET-1 pD2 value from $8.260 \pm 0.187$ of $\mathrm{TIH}$-denuded to $7.544 \pm 0.082$ of TIH-BQ123-denuded. Furthermore, it was significantly different at doses $\left(10-8 \mathrm{M}\right.$ and $\left.5 \times 10^{-8} \mathrm{M}\right)$ in comparison with $\mathrm{TIH}$-denuded as shown in the Table 1 and Figure 8.

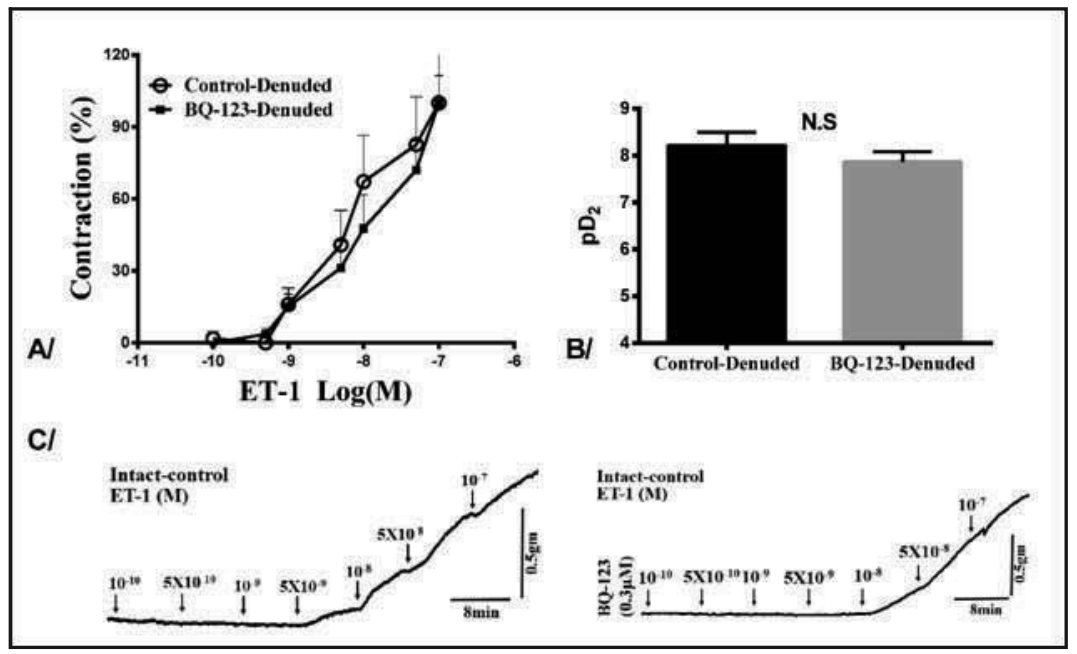

Figure 7: Dose-response contractile curve for ET-1 in denuded aortic rings with absence (Control) and presence of $\mathrm{ET}_{\mathrm{A}}$ receptor antagonist $(\mathrm{BQ} 123,0.3 \mu \mathrm{M})$ in rats with control $(\mathrm{A})$. The $\mathrm{pD}_{2}$ value for ET-1 (B). A Typical chart view traces $(\mathrm{C})$. Values represented as mean \pm S.E.

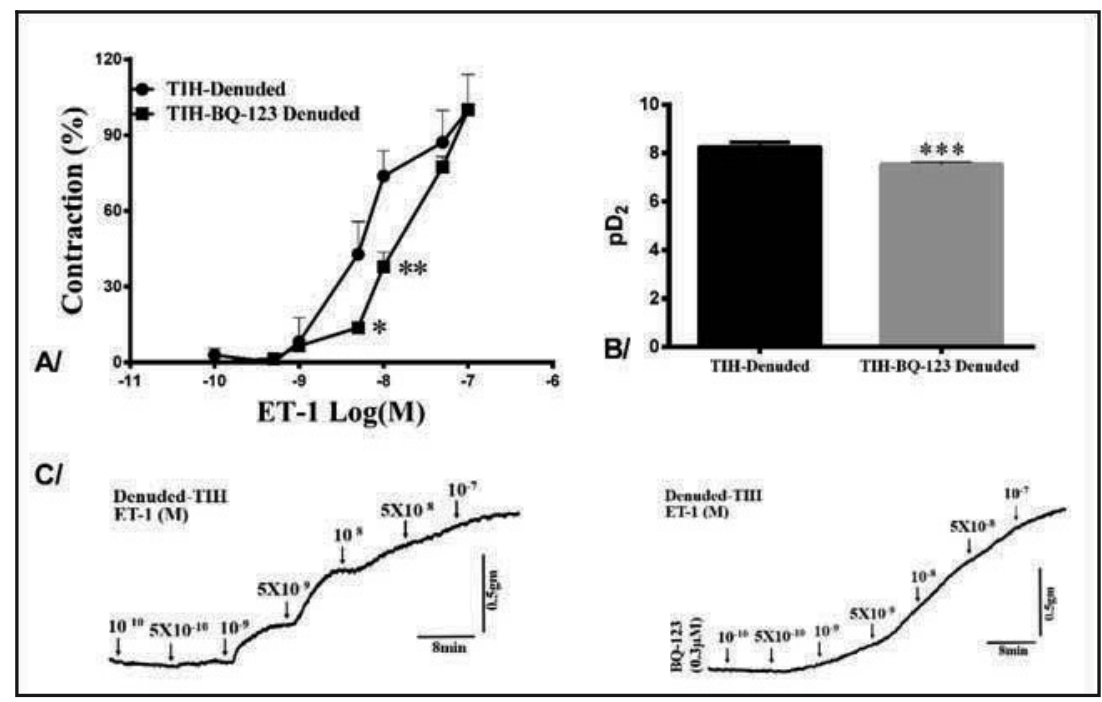

Figure 8: Dose-response contractile curve for ET-1 in denuded aortic rings with absence (Control) and presence of $\mathrm{ET}_{\mathrm{A}}$ receptor antagonist $(\mathrm{BQ} 123,0.3 \mu \mathrm{M})$ in rats with thyroxine-induced hyperthyroidism (TIH) (A). The $\mathrm{pD}_{2}$ value for $\mathrm{ET}-1$ (B). A Typical chart view traces $(\mathrm{C})$. The star sign show the comparison with $\mathrm{TIH}:{ }^{*} P<0.05,{ }^{* * *} P<0.001$. Values represented as mean \pm S.E. 


\section{Discussion}

The results obtained from the in vitro experiment revealed that I-thyroxine inducing hyperthyroidism did not significantly alter the dose-response curve of ET-1 and the pD2 value of ET-1with their Emax slightly decreased without being the significant change. The similar results obtained by the. ${ }^{14}$ In the VSMCs, both ETA and ETB receptors may couple to PLC via a GTP-binding protein. Activation of PLC causes phosphatidyl inositol hydrolysis, rapid formation of IP3, and accumulation of DAG. IP3 stimulates the release of $\mathrm{Ca} 2+$ from intracellular stores, including endoplasmic reticulum. ${ }^{15}$ Our data presented that endothelial denudation of aortic rings of control rats shifted the dose response curve of ET-1 to the left and increased pD2 value nonsignificantly. It confirms that ET-1 makes a vasocontraction via ETA receptor present on SMCs. ${ }^{16}$ Meanwhile, ET-1 induce contraction is endothelium independent. Tirapelli et al. (2005) reported that endothelium denudation leads to an enhancement in the Emax values with no differences in the pD2 value when compared to endothelium-intact carotid rings. ${ }^{17}$ Moreover, in the inducedhyperthyroid group, the endothelium denudation of aortic rings significantly shifted the DRC of ET-1 to the left, and the potency of ET-1 increased without changing the Emax compared to the intact aortic rings. Hyperthyroidism has a great effect on endothelium as previously described; it causes ED. This finding may be due some changes happened to ETA receptor on SMCs and may be overexpressed in hyperthyroid rats Incubation of control rat aortic rings with BQ-123 significantly inhibited the ET-1 induced contraction in a concentrationdependent manner and produced a rightward displacement of ET-1 dose response curve. Meanwhile, the pD2 value significantly decreased it means that the ET-1 potency decreased and the Emax slightly reduced compared to aortic rings
ET-1 DRC in the absence of BQ-123. He et al. (2007) recorded that the ETA antagonist $B Q-123$ induced a higher relaxation than the BQ-788 did in the ET-1-precontracted internal mammary artery. ${ }^{18}$ Marrachelli et al. (2006) reported that BQ-123 significantly inhibited the contractile response to ET-1 of renal arteries from control rabbits. ${ }^{19}$ Inversely, pre-incubation of endothelium-denuded control aortic rings with $\mathrm{BQ}-123$ did not significantly change the DRC of ET-1 with their pD2 and Emax value when compared to denuded aortic rings in the absence of $B Q-123$. These findings indicate that endothelium has a great role in relaxation. In contrast, the current result showed that in induced-hyperthyroid rats pre-incubation of aortic rings with $B Q-123$ did not make any significant change in dose-response curve induced by ET-1 compared to ET-1 $\mathrm{DRC}$ in the absence of BQ-123 incubation. Interestingly, endothelial denudation in induced-hyperthyroid rats pre-incubation of aortic rings with BQ-123 lead to a significant decrease in contractile potency of ET-1 induced contraction without the change in Emax value as well as the decrease in pD2 value. Accordingly, the main reason that caused this result may be due to ETA receptor expression up-regulated on SMCs of induced hyperthyroid rat aorta or due to ED caused by hyperthyroidism. In contrast, Donckier et al. (2003) reported that ET-1 and ETA receptor overexpressed in thyroid papillary carcinoma and Hashimoto's thyroiditis. ${ }^{13}$ Furthermore, pre-incubation of aortic rings of control rats with ETB receptor antagonist (BQ-788) significantly increased the $\mathrm{pD} 2$ of ET-1it means increases ET-1 potency while it is significantly declined the Emax in comparison with DRC of ET-1 in the absence of $B Q-788$. Previously it has been shown that pretreatment of mesenteric arteries with the BQ-788 significantly increased the potency of ET-1 in the Wistar group but led to the non-significant change inGoto-kaki Zaki diabetic group. ${ }^{20}$ The pD2 value of ET-1 of aortic rings incubated with 
BQ-788 significantly increased compared to aortic rings incubated with $B Q-123$, while Emax slightly decreased. In the present study, pre-incubation of aortic rings of induced-hyperthyroid rats with $\mathrm{BQ}-788$ shifted the DRC of ET-1 to the left. Despite, it is significantly increased the contractile potency of ET-1 with the significant increase in Emax of ET-1 in comparison with ET-1 DRC in the absence of BQ-788. This result may be due to inhibition of vasodilation effect of ETB receptor via a release of NO, prostacyclin and ATPgated $\mathrm{K}+$ channels $^{21}$. On the other hand, the Emax and pD2 of ET-1 incubated with BQ-788 of induced-hyperthyroid rats significantly higher than Emax and pD2 value of ET-1 incubated with BQ-123. So, the possible reason for the present results may be due to down-regulation of ETB receptor in aortic rings of induced hyperthyroidism.

\section{Conclusion}

In induced-hyperthyroid rats $B Q-788$, but not BQ-123 enhanced contractile response to ET-1Pre-incubation of BQ-123 did not lead to change the contractile response of denuded rings in control rats, but preincubation of this antagonist in hyperthyroid denuded aortic rings led to inhibition of contractile response to ET-1. These new findings taken together returned to ETA receptor activity located smooth muscle aortic rings in hyperthyroidism.

\section{References}

1. Yanagisawa M., Kurihara H., Kimura S, Tomobe $\mathrm{Y}$, Kobayashi M, Mitsui $\mathrm{Y}$, et al. A novel potent vasoconstrictor peptide produced by vascular endothelial cells. Nature 1988; 332:411-5.

2. Vignon-Zellweger N, Heiden S, Miyauchi T, Emoto $\mathrm{N}$. Endothelin and endothelin receptors in the renal and cardiovascular systems. Life Sciences 2012; 91:490-500.

3. Cardillo C, Kilcoyne C M, Waclawiw M, Cannon R O, 3Rd \& Panza J A. Role of Endothelin In The Increased Vascular Tone Of Patients With Essential Hypertension. Hypertension 1999; 33:753-8.

4. David F, Montezano A, Rebouças N, Nigro D, Fortes Z, Carvalho M, Tostes R. Gender differences in vascular expression of endothelin and Et $A / E t$ B receptors, But not in calcium handling mechanisms, In deoxycorticosterone acetate-salt hypertension. Brazilian journal of medical and biological research 2002; 35:10618.

5. Thorin E, Lucas M, Cernacek P, Dupuis J. Role of ETA receptors in the regulation of vascular reactivity in rats with congestive heart failure. American journal of physiology-heart and circulatory physiology 2000; 279:844-51.

6. De Mey J G, Compeer M G, Lemkens P, Meens M J. ET A-Receptor antagonists or allosteric modulators? trends in pharmacological sciences 2011; 32:345-51.

7. Ohuchi $T$, Kuwaki $T$, Ling $G Y$, Dewit $D$, Ju K H, Onodera M, Cao W H, Yanagisawa M, Kumada, M. Elevation of blood pressure by genetic and pharmacological disruption of the ETB receptor in mice. American Journal of Physiology-Regulatory, Integrative and comparative physiology 1999; 276:1071-7.

8. Ruffolo Jr, R. R. Endothelin receptors: From the gene to the human 1995; Crc Press.

9. Scanlon V C, Sanders T. Essentials of anatomy and physiology 2014; Fa Davis.

10. Kedzierski R M, Yanagisawa M. Endothelin system: The double-edged sword in health and disease. Annual review of pharmacology and toxicology $2001 ; 41: 851-76$.

11. Tamer I, Sargin $M$, Sargin $H$, Seker $M$, Babalik E, Tekce M, et al. The evaluation of left ventricular hypertrophy in hypertensive patients with Subclinical hyperthyroidism. Endocr J 2005; 52.

12. Canaris G J, Manowitz N R, Mayor G, Ridgway E C. The Colorado Thyroid Disease Prevalence Study. Arch Intern Med 2000; 160:526-34.

13. Donckier J E, Michel L, Van Beneden R, Delos $M$, Havaux $X$. Increased expression of endothelin-1 and its mitogenic receptor ETA in human papillary thyroid carcinoma. Clinical Endocrinology 2003; 59:354-60.

14. Mcallister R M, Luther K L, Pfeifer P C. Thyroid status and response to endothelin-1 in rat arterial vessels. American Journal of PhysiologyEndocrinology and Metabolism 2000; 279:252-8.

15. Katzung G, Bourne $H$, Von Zastrow M, Holford $\mathrm{N}$, Correia M, Berkowitz B. Basic principles of pharmacology. Basic and clinical pharmacology, 12th edition 2010; New York: Mcgraw-Hill Medical.

16. Barrett K E, Ghishan F K, Merchant J L, Said H $M$, Wood J D, Johnson L R. Physiology of the gastrointestinal tract, elsevier science 2006.

17. Tirapelli C R, Casolari D A, Yogi A, Montezano A C, Tostes R C, Legros E, et al. Functional characterization and expression of endothelin receptors in rat carotid artery: Involvement of nitric oxide, A vasodilator prostanoid and the opening of $\mathrm{K}+$ channels in ETB-induced relaxation. British journal of 
pharmacology 2005; 146:903-12

18. He GW, Liu MH, Yang Q, Furnary A, Yim AP. Role of endothelin-1 receptor antagonists in vasoconstriction mediated by endothelin and other vasoconstrictors in human internal mammary artery. The annals of thoracic surgery 2007; 84:1522-7.

19. Marrachelli VG, Miranda FJ, Alabadí, JA, Lloréns $\mathrm{S}$, Alborch $\mathrm{E}$. Contribution of endothelin receptors and cyclooxygenase-derivatives to the altered response of the rabbit renal artery to endothelin-1 in diabetes. European journal of pharmacology 2006; 534:178-86.

20. Matsumoto T, Ishida K, Nakayama N, Kobayashi T, Kamata K. Involvement of no and MEK/ERK Pathway In Enhancement Of Endothelin1-Induced Mesenteric Artery Contraction In Later-Stage Type 2 Diabetic Goto-Kakizaki Rat. American Journal Of Physiology-Heart And Circulatory Physiology 2009; 296:1388-97.

21. Yuan J X J, Garcia J G N, Hales C A, Rich S, Archer S L, West J B. Textbook Of Pulmonary Vascular Disease 2011; Springer Us. 